\title{
ARSENIC TOXICITY IN Acacia mangium WILLD. AND Mimosa caesalpiniaefolia BENTH. SEEDLINGS ${ }^{(1)}$
}

\author{
Henrique Nery Cipriani ${ }^{(2)}$, Luiz Eduardo Dias ${ }^{(3)}$, Maurício Dutra Costa ${ }^{(4)}$, Naiara Viana \\ Campos $^{(5)}$, Aristéa Alves Azevedo ${ }^{(6)}$, Roberto Junio Gomes ${ }^{(7)}$, Izabela Ferreira Fialho ${ }^{(8)}$ \& \\ Sandra Patrícia Montealegre Amezquita ${ }^{(9)}$
}

\begin{abstract}
SUMMARY
Acacia mangium and Mimosa caesalpiniaefolia are fast-growing woody fabaceous species that might be suitable for phytoremediation of arsenic (As)contaminated sites. To date, few studies on their tolerance to As toxicity have been published. Therefore, this study assessed As toxicity symptoms in A. mangium and M. caesalpiniaefolia seedlings under As stress in a greenhouse. Seedlings of Acacia mangium and $M$. caesalpiniaefolia were grown for $120 \mathrm{~d}$ in an Oxisol-sand mixture with $0,50,100,200$, and $400 \mathrm{mg} \mathrm{kg}^{-1} \mathrm{As}$, in four replications in four randomized blocks. The plants were assessed for visible toxicity symptoms, dry matter production, shoot/root ratio, root anatomy and As uptake. Analyses of variance and regression showed that the growth of $A$. mangium and $M$. caesalpiniaefolia was severely hindered by As, with a reduction in dry matter production of more than $80 \%$ at the highest As rate. The root/shoot ratio increased with increasing As rates. At a rate of $400 \mathrm{mg} \mathrm{kg}^{-1} \mathrm{As}$, whitish chlorosis appeared on Mimosa caesalpiniaefolia seedlings. The root anatomy of both species was altered, resulting in cell collapse, death of root buds and accumulation of phenolic compounds. Arsenic concentration was several times greater in roots than in shoots, with more than 150 and $350 \mathrm{mg} \mathrm{kg}^{-1}$ in $M$. caesalpiniaefolia and $A$. mangium roots, respectively. These species could be suitable for phytostabilization of As-contaminated sites, but growth-stimulating measures should be used.

Index terms: arsenate, heavy metals, phytoremediation, root anatomy, soil contamination.

\footnotetext{
(1) Part of the first author's Dissertation, Departament of Soils - DPS, Universidade Federal de Viçosa - UFV. Received for publication on November 28, 2012 and approved on June 24, 2013.

(2) Researcher, Embrapa Rondônia, BR 364, km 5,5, Cidade Jardim. CEP 76815-800 Porto Velho (RO), Brazil. E-mail: henrique.cipriani@embrapa.br

(3) Professor, DPS, UFV. Av. P. H. Rolfs, s/n. CEP 36570-000 Viçosa (MG), Brazil. E-mail: ledias@ufv.br

(4) Professor, Departament of Microbiology - DMB, UFV. E-mail: mdcosta@ufv.br

(5) Doctoral student, Departament of Vegetable Biology - DBV, UFV. E-mail: camposnv@yahoo.com.br

(6) Professor, DBV, UFV. E-mail: aazevedo@ufv.br

(7) Master student, DPS, UFV. E-mail: robertojgomes@yahoo.com.br

(8) Undergraduate student, DBV, UFV. E-mail: izabela.fialho@ufv.br

${ }^{(9)}$ Forest Engineer, Inverbosques. Cr 43 A \# 16 a sur 38, Edificio DHL, of 1002 Medellín, Colombia. E-mail: sandramont2@hotmail.com
} 
RESUMO: TOXIDEZ POR ARSÊNIO EM Acacia mangium WILLD. E Mimosa caesalpiniaefolia $B E N T H$.

\begin{abstract}
Acacia mangium e Mimosa caesalpiniaefolia são fabáceas lenhosas de rápido crescimento cuja tolerância à toxidez por arsênio (As) deve ser estudada para avaliação do potencial de fitorremediação. Assim, este experimento, conduzido em casa de vegetação, objetivou avaliar sintomas de toxidez por As em A. mangium e M. caesalpiniaefolia. Plantas seminais de A. mangium e M. caesalpiniaefolia foram cultivadas por $120 \mathrm{~d}$ em uma mistura de Latossolo Vermelho e areia, contaminadas com 0, 50, 100, 200 e $400 \mathrm{mg} \mathrm{kg}^{-1}$ de As. Utilizaram-se quatro repetições distribuidas em quatro blocos casualizados. Foram avaliados os sintomas visíveis de toxidez, a produção de matéria seca, a relação raiz / parte aérea, a anatomia radicular e o acúmulo de As. As análises de variância e de regressão evidenciaram que o crescimento das plantas foi prejudicado pelo As, excedendo $80 \%$ de redução da produção de matéria seca na maior dose. A relação raiz/parte aérea aumentou com a adição de As. Plantas de M. caesalpiniaefolia manifestaram clorose esbranquiçada sob $400 \mathrm{mg} \mathrm{kg}^{-1} \mathrm{de} \mathrm{As}$. A anatomia radicular das espécies foi alterada, observando-se células colapsadas, morte de primórdios radiculares e acúmulo de compostos fenólicos. A concentração de As nas raízes foi dezenas de vezes superior à concentração na parte área, excedendo 150 e $350 \mathrm{mg} \mathrm{kg}^{-1} \mathrm{na} \mathrm{M}$. caesalpiniaefolia e na A. mangium, respectivamente. Essas espécies apresentaram potencial para fitoestabilização de áreas contaminadas com As, porém devem ser adotadas medidas para promover seu crescimento nesses locais.
\end{abstract}

Termos de indexação: anatomia radicular, arsenato, contaminação do solo, fitorremediação, metais pesados.

\section{INTRODUCTION}

Arsenic (As) is a relatively abundant and widely spread metalloid, present in the air, water and soil (Mandal \& Suzuki, 2002; Bundschuh et al., 2012). The major natural pathways for As accumulation are mineral weathering and volcanic eruptions, whereas mining, ore smelting, agrochemicals and wood preservatives are important anthropogenic sources (Mandal \& Suzuki, 2002; Kyle et al., 2011). Arsenic is toxic to living organisms, since it disrupts many metabolic processes, but its toxicity level depends on the (organic or inorganic) origin and oxidation state (Kyle et al., 2011). Usually, in a less oxidized state, as in As(III) (arsenite), arsenic is more toxic and the organic As forms are less toxic than their organic counterparts (Litter et al., 2008).

Although the anthropogenic sources are largely responsible for the As contamination of soil and water, in some regions with abundance of sulphides and arsenic-minerals in the subsoil, the As concentration in drinking water and soil may naturally reach hazardous levels (Borba et al., 2000; Mandal \& Suzuki, 2002; Vaughan, 2006; Bundschuh et al., 2012). Therefore, a number of methods to decontaminate soil and water have been developed, of which phytoremediation is one of the most environment-friendly and least costly (Marques et al., 2009; Nascimento et al., 2009; Litter et al., 2012).

For phytoremediation, the use of adequate species is of utmost importance. There is no species that would suit all existent combinations of substrate, climate and contamination levels. However, there are some common factors that should be considered in the search for useful plants (Pulford \& Dickinson, 2005; Gonzaga et al., 2006): high biomass, economic value, public acceptance, site stabilization and high contaminant-uptake capacity.

In this regard, Acacia mangium Willd. and Mimosa caesalpiniaefolia Benth. are promising species for phytoremediation. Both are fast-growing tropical fabaceous woody species with a wide application spectrum (e.g. timber, lumber, coal, and landscaping), tolerant to infertile soils and with high $\mathrm{N}$-fixation capacity (Franco \& Balieiro, 1999; Ribaski et al., 2003; Marto, 2007; Wang et al., 2010). Despite their rusticity, few studies were published on the performance of $M$. caesalpiniaefolia and A. mangium on arsenic-contaminated sites (Costa, 2007; Dias et al., 2007). Therefore, the aim of this study was to assess the arsenic toxicity in Acacia mangium Willd. and Mimosa caesalpiniaefolia Benth.

\section{MATERIAL AND METHODS}

The experiment was carried out in a greenhouse of the Universidade Federal de Viçosa (UFV), Viçosa, Minas Gerais, in Southeastern Brazil, from June 27 to October 27, 2010.

The experimental design was full factorial, testing two plant species (Acacia mangium and Mimosa caesalpiniaefolia) at five arsenic rates $(0,50,100$, 200 and $400 \mathrm{mg} \mathrm{kg}^{-1}$ ), totaling 10 treatments, with four replications in four completely randomized blocks. Two plants were grown per pot; therefore, 
all results represent the mean of two plants, except for arsenic content, corresponding to the whole sample unit.

The substrate consisted of an autoclaved mixture of three quarter of an Oxisol to one quarter of coarse sand $(\mathrm{v} / \mathrm{v})$. Black plastic pots $(3 \mathrm{~L})$ were filled with 2.5 $\mathrm{kg}$ of the substrate. Thirty-five days before sowing, a mixture of three quarters of $\mathrm{CaCO}_{3}$ to one quarter of $\mathrm{MgCO}_{3}(\mathrm{w} / \mathrm{w})$ was mixed into each pot, to achieve $50 \%$ of base saturation. After this liming, the substrate moisture was maintained at $0.17 \mathrm{~kg}$ water per $\mathrm{kg}$ of substrate, approximately, until the end of the experiment.

Arsenic was applied 15 days after liming, as $\mathrm{As}_{2} \mathrm{O}_{3}$ dissolved in $2 \mathrm{~mol} \mathrm{~L}^{-1}$ potassium hydroxide $(\mathrm{KOH})$ solution, at $0,50,100,200$ and $400 \mathrm{mg} \mathrm{kg}^{-1}$ As. Potassium was applied equally to all treatments at $0.46 \mathrm{~g} \mathrm{~kg}^{-1}$, as KOH solution. Nine days before sowing, $0.30 \mathrm{~g}$ of anhydrous calcium phosphate $\left(\mathrm{CaHPO}_{4}\right)$ was mixed into each pot to correct extreme phosphorus deficiency (available $\mathrm{P}$ in the substrate was $3.3 \mathrm{mg}$ $\mathrm{dm}^{-3}$ before $\mathrm{CaHPO}_{4}$ addition).

Chemical and physical analyses (Embrapa, 1997) were performed with substrate samples taken from the pots at sowing (Table 1). The plant-available As (Mehlich-3) in the substrate was $0.00,0.76,3.63,8.82$, and $29.65 \mathrm{mg} \mathrm{dm}^{-3}$ in the pots which received 0,50 , 100,200 , and $400 \mathrm{mg} \mathrm{kg}^{-1} \mathrm{As}$, respectively.

Considering the amounts of $\mathrm{P}$ and $\mathrm{K}$ in the substrate (Table 1), additional fertilization was supplied fortnightly, beginning 30 days after sowing, with the application of $3 \mathrm{~mL}$ of Hoagland solution (excluding $\mathrm{P}$ and $\mathrm{K}$ ) per pot, diluted in irrigation water. During the third month of cultivation, $3 \mathrm{~mL}$ of $1 \mathrm{~mol} \mathrm{~L}^{-1} \mathrm{NaH}_{2} \mathrm{PO}_{4}$ solution was applied three times for supplementary $\mathrm{P}$ supply.

After 120 days of cultivation, the plants were collected for the assessment of root and shoot dry matter (RDM and SDM) and root/shoot ratio (RSR), based on dry matter production. To allow a comparison between species, the analyses were based on the growth in relation to the corresponding control treatment (without arsenic). Visible toxicity symptoms were described when manifested. The concentration of plant-available As that resulted in a reduction of $50 \%$ of total dry matter ( $\mathrm{SAs}_{50} \%$ ) was estimated by regression equations for plant-available As as a function of the applied As rate.

Fragments obtained from cross sections of apical and intermediate roots were collected for light microscopy. Soon after collection, the fragments were fixed in $0.25 \mathrm{~mol} \mathrm{~L}^{-1}$ glutaraldehyde and $1.33 \mathrm{~mol} \mathrm{~L}^{-1}$ paraformaldehyde in sodium calcodylate buffer $(\mathrm{pH}$ 7.2) plus $5 \mathrm{mmol} \mathrm{L}^{-1}$ calcium chloride (Karnovsky, 1965). The fragments were then dehydrated in increasing alcohol series and embedded in methacrylate (Historesin).

The root and shoot As concentrations were determined from finely ground dried samples subjected to 3:1 nitric-perchloric digestion (Tedesco et al., 1995). Before grinding, shoot samples were washed with distilled water. The root samples were washed with tap water, bathed for $1 \mathrm{~min}$ in $0.1 \mathrm{~mol} \mathrm{~L}^{-1} \mathrm{HCl}$ to remove As adhered to the root surface, and then rinsed with distilled water.

The quantification of the As levels in the extracts was performed by inductively coupled plasma optical emission spectrometry (ICP-OES). The contents were calculated by multiplying dry matter by the As concentration. Translocation indexes were calculated by dividing the shoot As content by the As content of the whole plant.

Data normality and homoscedasticity were verified by Ryan-Joiner and Bartlett tests, respectively, at $1 \%$ significance. To correct possible deviations from normality or heteroscedasticity, the Box-Cox transformation was applied. In case of inefficiency of the first transformation, Johnson's transformation was used alternatively. Afterwards, analysis of variance was performed at $5 \%$ significance to test the treatment effects.

Regression analysis was performed by adjusting linear, quadratic and square-root dose-response curves. For each variable, the best model was considered the one with a coefficient of determination greater than or equal to 0.70 and the smallest number of significant parameters, using Sisvar and Minitab 16 software for the statistical analyses.

Table 1. Soil chemical and physical properties before sowing(1)

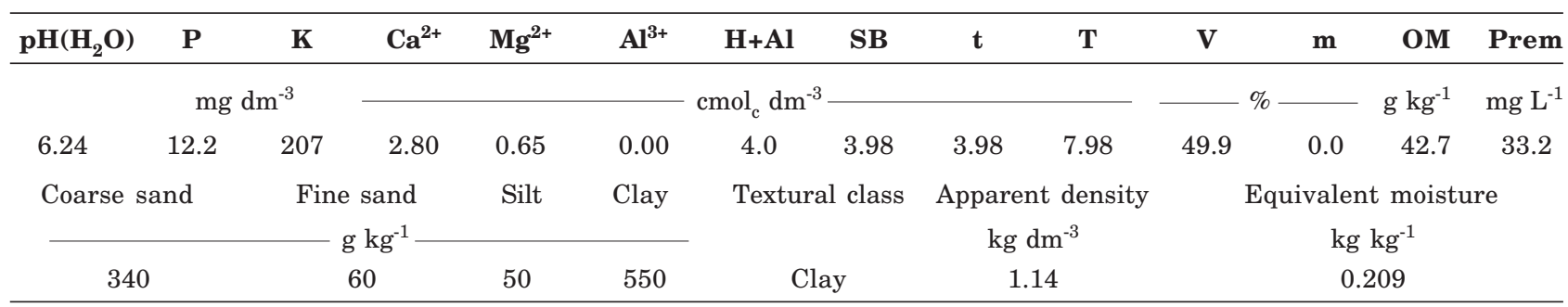

SB: sum of bases; t: effective cation exchange capacity $\left(\mathrm{SB}+\mathrm{Al}^{3+}\right)$; $\mathrm{T}$ : cation exchange capacity at $\mathrm{pH} 7(\mathrm{SB}+\mathrm{H}+\mathrm{Al})$; V: base saturation (100 SB/T); m: Al saturation (100 Al/t); OM: organic matter; P-rem: remaining phosphorus. ${ }^{(1)}$ According to Embrapa (1997) 


\section{RESULTS AND DISCUSSION}

Root, shoot and total dry matter of $A$. mangium and $M$. caesalpiniaefolia decreased $(\mathrm{p}<0.01)$ with increasing arsenic rates, in a quadratic model (Figure 1), except for M. caesalpiniaefolia RDM, which did not fit the tested models. Total dry matter yield reduction reached $80 \%$ for $M$. caesalpiniaefolia and $90 \%$ for $A$. mangium. This result could be due to impairment of some metabolic processes by arsenic, such as ATP and chlorophyll synthesis, photosynthesis, cell division, and induction of oxidative stress and water stress (Dho et al., 2010; Zhao et al., 2010; Czech et al., 2011; Garg \& Singla, 2011; Nascimento et al., 2011). The disruption of these processes often has a cumulative effect, culminating in severe growth reduction.

The plant-available As concentration that induced a reduction of $50 \%$ in total dry matter $\left(\mathrm{SAs}_{50 \%}\right)$ was 2.17 and $2.84 \mathrm{mg} \mathrm{dm}^{-3}$, respectively, for A. mangium and $M$. caesalpiniaefolia, indicating that the former species may be more sensitive to As than the latter. These concentrations correspond to As rates of 87 and $105 \mathrm{mg} \mathrm{kg}^{-1}$, approximately. The $\mathrm{SAs}_{50 \%}$ values found in this study are several times lower than those found for other shrub (Dias et al., 2010) and tree species (Melo et al., 2010). They are also below the prevention level of $15 \mathrm{mg} \mathrm{kg}^{-1}$ recommended for Brazilian soils (Brasil, 2009).

The increase of the root/shoot ratio (RSR) $(\mathrm{p}<0.01)$ in both species (Figure 1) indicated a more pronounced growth reduction in shoots than in roots. In Acacia mangium, RSR increased linearly, whereas in $M$. caesalpiniaefolia, the RSR increase followed a quadratic model (Figure 1). The RSR behavior is probably related to the tolerance mechanism of the species against As toxicity. The defense mechanism of nonhyperaccumulating plants usually involves vacuolar sequestration of As bound to phytochelatins in root cells (Zhao et al., 2009). Therefore, more energy may have been spent to sustain root growth and improve As sequestration. Also, since As mobility in soils is relatively low, root growth may permit reaching soil sites with lower As availability.

Despite the increase in RSR, root formation was hindered by As, increasing the proportion of abnormal roots. In A. mangium a thickening of the root cap, mucilage excretion and accumulation of phenolic compounds were observed (Figure 2a). In $M$. caesalpiniaefolia roots, besides phenolic compound accumulation and mucilage excretion, death of lateral root buds and root wrinkling occurred hindering the establishment of straight longitudinal cuts (Figure 2d).

The extension of root damage due to As toxicity differs among species and could be an indicator to differentiate resistant from vulnerable species (Silva, 2008; Deng et al., 2010; Pereira et al., 2011; Schneider et al., 2012). Pereira et al. (2011), for instance, observed no root damage in Eichhornia crassipes, considered a tolerant species, grown in nutrient solution with $2.0 \mathrm{mg} \mathrm{L}^{-1} \mathrm{As}$. On the contrary, root
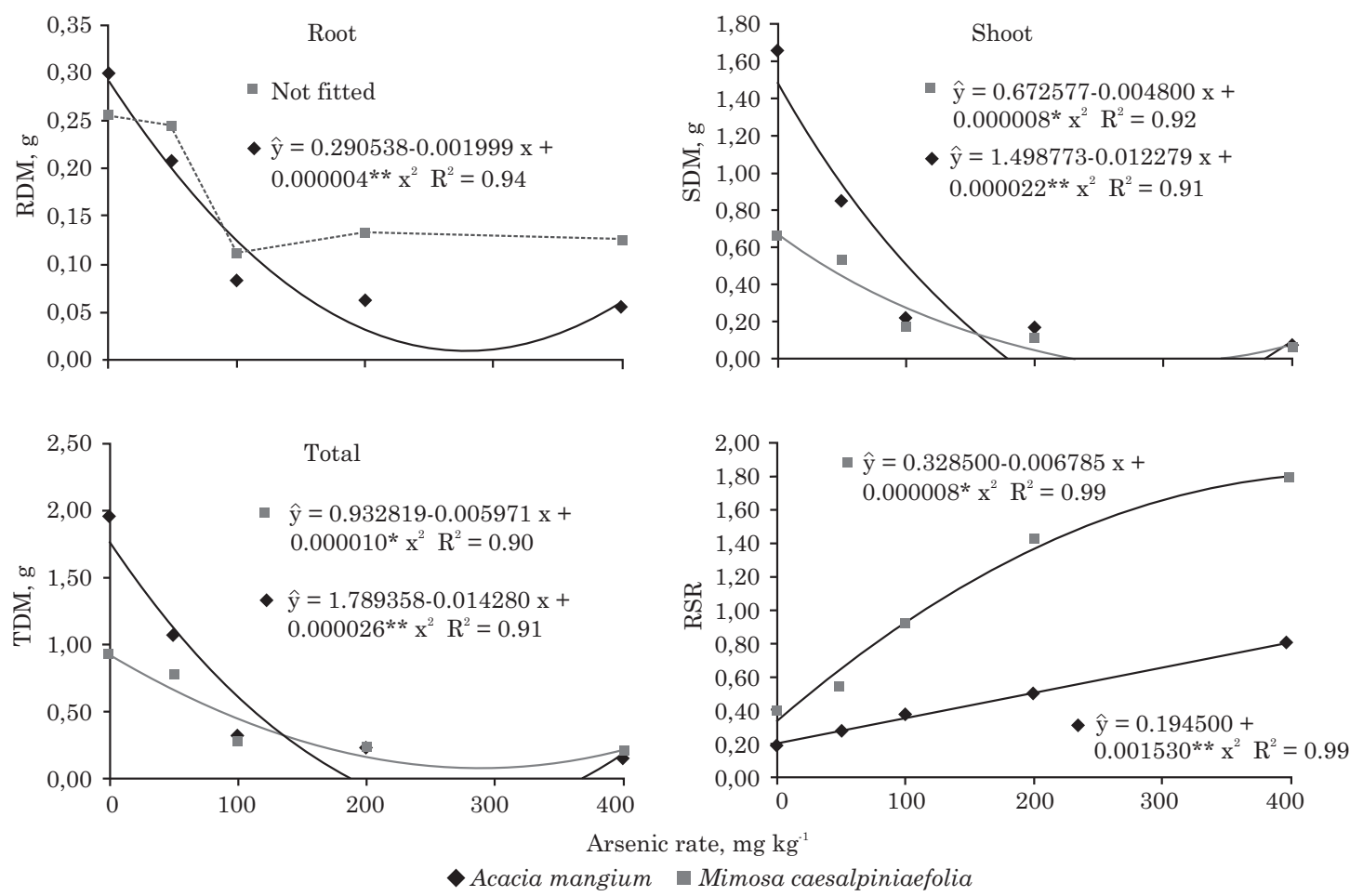

Figure 1. Root dry matter (RDM), shoot dry matter (SDM), total dry matter (TDM) and root/shoot ratio (RSR) of Acacia mangium ( $\bullet$ ) and Mimosa caesalpiniaefolia $(\square)$ seedlings as a function of the arsenic rate added to the substrate. * and **: significant at the 5 and $1 \%$, respectively. 


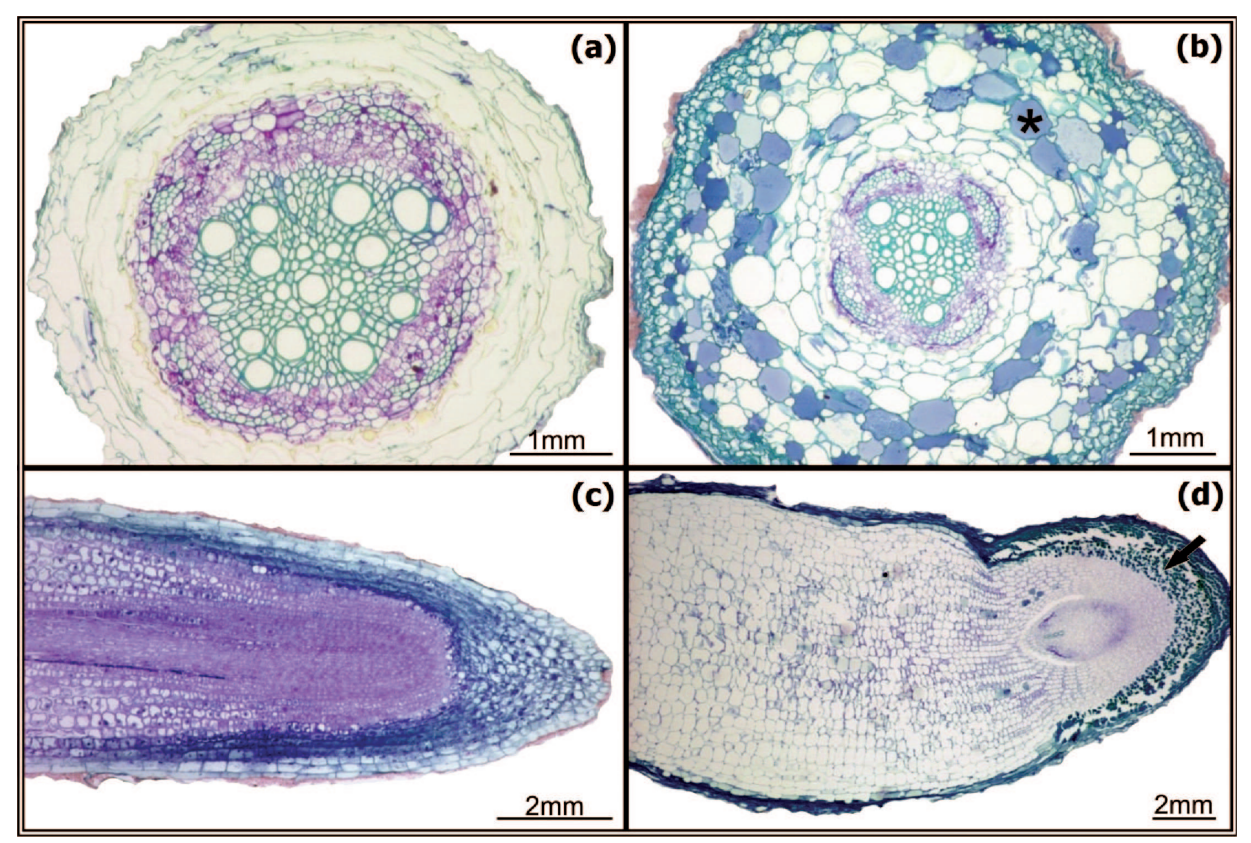

Figure 2. Main root structure of Acacia mangium (a and b; transverse cut) and root apex structure of Mimosa caesalpiniaefolia (c and d; longitudinal cut) after 60 d growing on a clayey substrate. A and C: Control treatment. B and D: treatment with $400 \mathrm{mg} \mathrm{kg}^{-1}$ As. * Phenolic compound accumulation in cortical parenchyma cells. Arrow: Dead cells near the root cap.

damage similar to that found in this study was observed in Schinus terebinthifolius, Borreria verticillata and Cajanus cajan, grown in nutrient solution with $2.5 \mathrm{mg} \mathrm{L}^{-1} \mathrm{As}$ (Silva, 2008), and Leucaena leucocephala in soil with $35 \mathrm{mg} \mathrm{dm}^{-3} \mathrm{As}$ (Schneider et al., 2012).

The accumulation of phenolic compounds in root cells is another response to As contamination (Silva, 2008). Phenolic compounds have antioxidant properties in plant metabolism (Grael et al., 2010). Therefore, phenolic compound accumulation could be a means of reducing the oxidative stress induced by arsenic (Zhao et al., 2010; Nascimento et al., 2011). However, the determination of the quantity and quality of these compounds required to improve As resistance will need further studies.

Sridhar et al. (2011) observed clumpy deposits on the roots and stem of As-contaminated Pteris vittata, a hyperaccumulating fern. The authors suggested these deposits could be related to a detoxification mechanism. In fact, the detoxification mechanisms of hyperaccumulating ferns probably differ from those of non-hyperaccumulating plants. Studying and comparing these mechanisms may improve the screening and management of species suitable for phytoremediation of As-contaminated sites.

By the end of the first month, chlorosis symptoms appeared on young leaves of Mimosa caesalpiniaefolia plants treated with $400 \mathrm{mg} \mathrm{kg}^{-1}$ As. In the most advanced stage, the leaf blade color turned paper-white, whereas the nerves remained green. Most plants recovered from chlorosis by the fourth month; however, their growth was severely impaired. Shaibur et al. (2008) also observed whitish chlorosis in barley grown in an As-contaminated solution, which was ascribed to induced Fe deficiency. The chlorosis observed in $M$. caesalpiniaefolia plants could also indicate chlorophyll degradation (Zhao et al., 2010; Garg \& Singla, 2011; Wang et al., 2012).

The As concentration in roots and shoot increased with increasing As rates ( $p<0.01$ ), however the best fitting model varied according to the species and organ (Figure 3). There was no significant difference ( $>0.05$ ) between $A$. mangium and $M$. caesalpiniaefolia regarding shoot As concentration. On the other hand, more arsenic was found in $A$. mangium roots $(\mathrm{p}<0.01)$. The As concentration in roots was much higher than in shoots for both species (Figure 3).

A clear tendency of increase $(p<0.01)$ in the As content was found for total and $\operatorname{root}$ As content of $M$. caesalpiniaefolia, which could be described by the square-root model (Figure 4). The effect of As rate on As content was significant $(p<0.01)$ for the other treatments, but could not be described by the tested models (Figure 4). The As translocation indices were not statistically different $(p>0.05)$ between species and were not significantly affected ( $p>0.05)$ by the As rates (Figure 4). Acacia mangium accumulated more As than $M$. caesalpiniaefolia, considering roots $(\mathrm{p}<0.01)$ and total $(\mathrm{p}<0.05)$ contents (Figures 4$)$. This indicates that $A$. mangium can stabilize or extract more As from contaminated soils. 


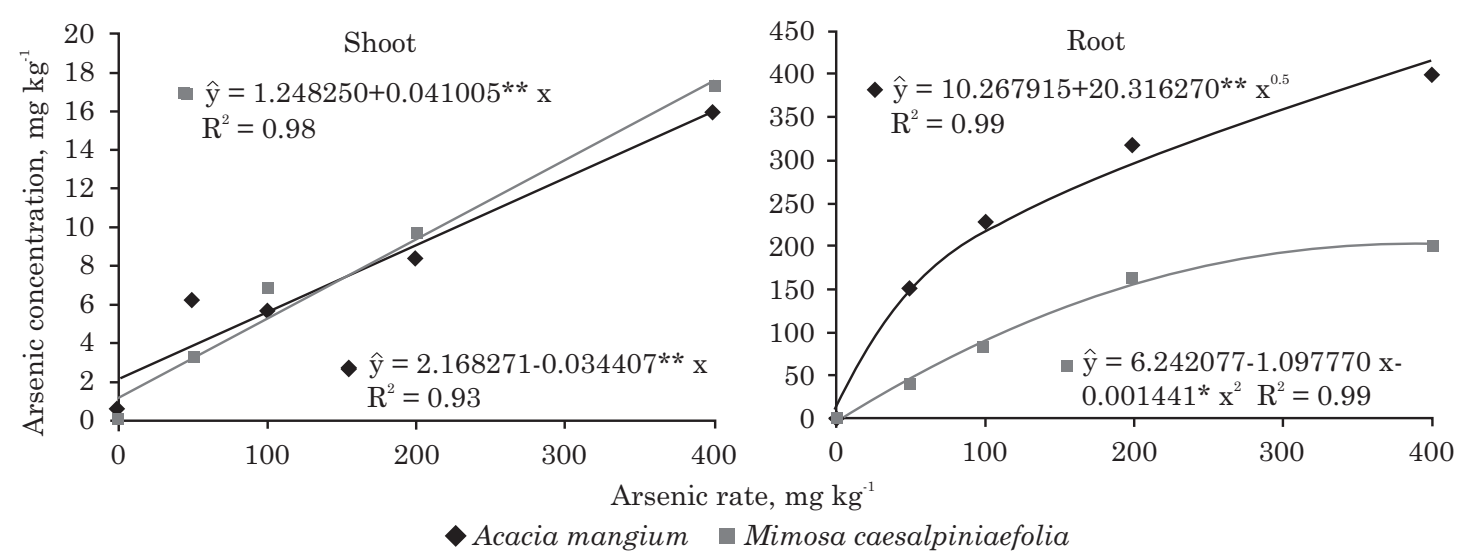

Figure 3. Arsenic concentration in the shoot (SAs) and the root (RAs) of Acacia mangium ( $\bullet$ ) and Mimosa caesalpiniaefolia ( $\square$ ) seedlings as a function of the As rate added to the substrate. * and ** Significant at 5 and $1 \%$ significance, respectively.
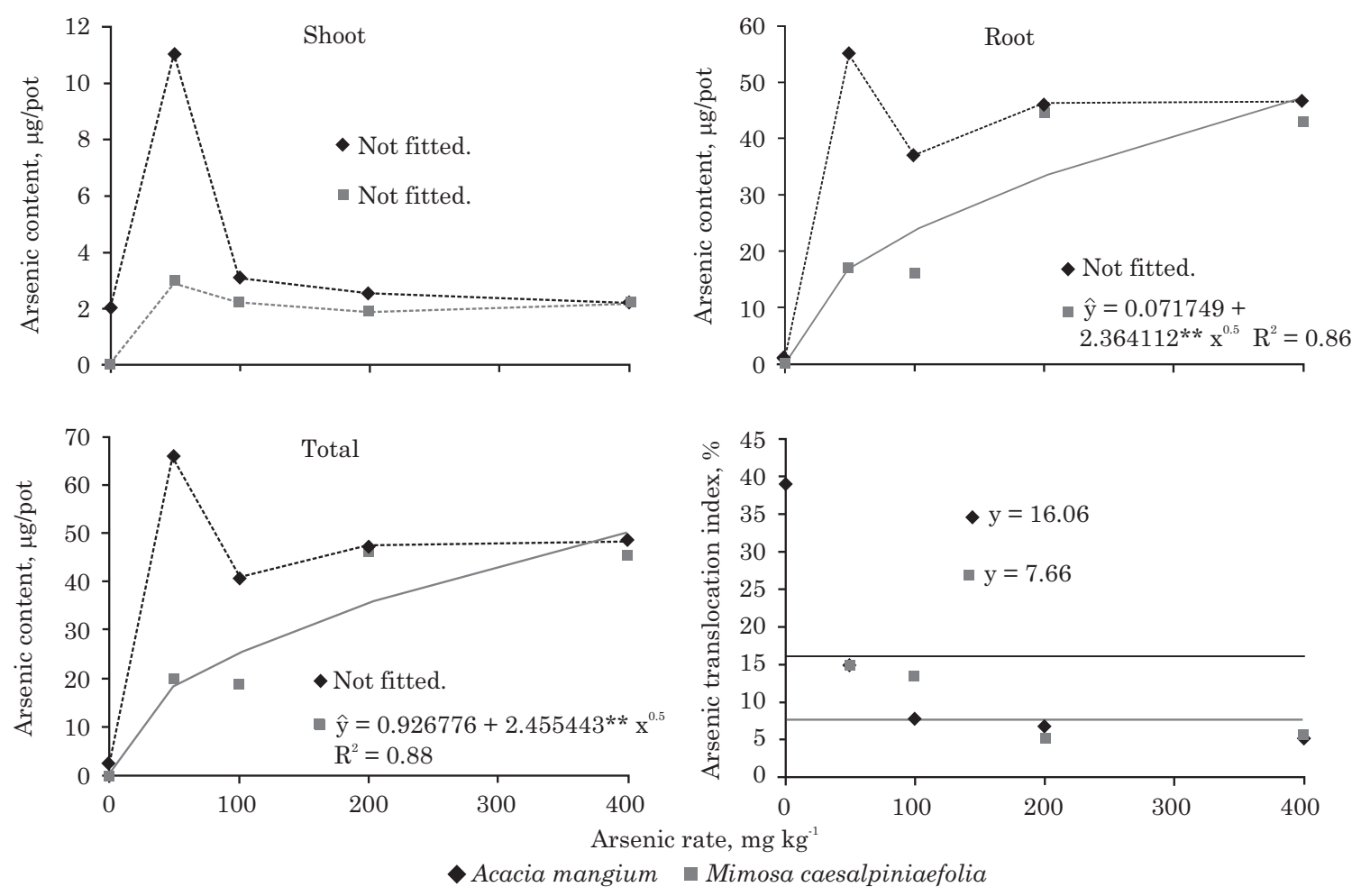

Figure 4. Arsenic content in the shoot (SAsC), root (RAsC), whole plant (TAsC) and As translocation index (AsTI) of Acacia mangium ( $\bullet$ ) and Mimosa caesalpiniaefolia ( $\square$ ) seedlings as a function of the As rate added to the substrate. $* *$ Significant at $1 \%$ significance.

The As concentrations found in A. mangium and M. caesalpiniaefolia were similar to those in other tropical shrub and tree species, such as Cajanus cajan, Sesbania virgata, Leucaena leucocephala, Eucalyptus grandis and E. cloeziana, tested under comparable experimental conditions (Dias et al., 2010; Melo et al., 2010). Although none of these species hyperaccumulates arsenic, their uptake capacity suggests their use for phytostabilization of As-contaminated sites. However, the low initial growth of A. mangium and $M$. caesalpiniaefolia observed in this study indicates that these species might not be efficient for this purpose. On the other hand, some well-known agronomic practices, such as phosphate fertilization or inoculation with mycorrhizal fungi, improve plant growth in Ascontaminated sites (Madeira et al., 2010; Santos et al., 2010; Cozzolino et al., 2010). Further studies should test these practices for $M$. caesalpiniaefolia and $A$. mangium. 


\section{CONCLUSIONS}

1. Arsenic greatly reduces the growth of Acacia mangium and Mimosa caesalpiniaefolia seedlings. Shoot growth is relatively more hindered than root growth.

2. Arsenic impairs root formation, increasing the number of collapsed cells and accumulation of phenolic compounds.

3. Acacia mangium and Mimosa caesalpiniaefolia accumulates large amounts of arsenic on roots, especially $A$. mangium. However, they are not hyperaccumulating plants.

\section{ACKNOWLEDGEMENTS}

The authors are indebted to the Fundação de Amparo à Pesquisa do Estado de Minas Gerais (FAPEMIG) for the Master scholarship of the first author. They also acknowledge the anonymous reviewers who helped improve the article.

\section{LITERATURE CITED}

BORBA, R.P.; FIGUEIREDO, B.R.; RAWLINS, B. \& MATSCHULLAT, J. Arsenic in water and sediment in the Iron Quadrangle, state of Minas Gerais, Brazil. R. Bras. Geoci., 30:558-561, 2000.

BRASIL. Conselho Nacional do Meio Ambiente. Resolução no 420, de 28 de dezembro de 2009. (DOU, 249:81-84, 2009)

BUNDSCHUH, J.; LITTER, M.I.; PARVEZ, F.; ROMÁN-ROSS, G.; NICOLLI, H.B.; JEAN, J.S.; LIU, C.W.; LÓPEZ, D.; ARMIENTA, M.A.; GUILHERME, L.R.G.; CUEVAS, A.G.; CORNEJO, L.; CUMBAL, L. \& TOUJAQUEZ, R. One century of arsenic exposure in Latin America: A review of history and occurrence from 14 countries. Sci. Total Environ., 429:2-35, 2012.

COSTA, A.C. Bases fisiológicas da ação do arsênio em algumas espécies de cerrado. Viçosa, MG, Universidade Federal de Viçosa, 2007. 78p. (Tese de Doutorado)

COZZOLINO, V.; PIGNA, M.; MEO, V.D.; CAPORALE, A.G. \& VIOLANTE, A. Effects of arbuscular mycorrhizal inoculation and phosphorus supply on the growth of Lactuca sativa L. and arsenic and phosphorus availability in an arsenic polluted soil under non-sterile conditions. App. Soil Ecol., 45:263-268, 2010.

CZECH, V.; CSEH, E. \& FODOR, F. Arsenate induces water stress. J. Plant. Nutr., 34:60-70, 2011.

DENG, D.; WU, S.-C.; WU, F.-Y.; DENG, H. \& WONG, M.-H. Effects of root anatomy and Fe plaque on arsenic uptake by rice seedlings grown in solution culture. Environ. Pollut., 158:2589-2595, 2010.
DHO, S.; CAMUSSO, W.; MUCCIARELLI, M. \& FUSCONI, A. Arsenate toxicity on the apices of Pisum sativum L. seedling roots: Effects on mitotic activity, chromatin integrity and microtubules. Environ. Exp. Bot., 69:1723, 2010 .

DIAS, L.E.; FRANCO, A.A. \& CAMPELLO, E.F.C. Fertilidade do solo e seu manejo em áreas degradadas. In: NOVAIS, R.F.; ALVAREZ V., V.H.; BARROS, N.F.; FONTES, R.L.F.; CANTARUTTI, R.B. \& NEVES, J.C.L., eds. Fertilidade do solo. Viçosa, MG, Sociedade Brasileira de Ciência do Solo, 2007. p.955-990.

DIAS, L.E.; MELO, R.F.; MELLO, J.W.V.; OLIVEIRA, J.Á. \& DANIELS, W.L. Growth of seedlings of pigeon pea (Cajanus cajan (L.) Millsp), wand river hemp (Sesbania virgata (Cav.) Pers.), and lead tree (Leucaena leucocephala (Lam.) de Wit) in an arsenic-contaminated soil. R. Bras. Ci. Solo, 34:975-983, 2010.

EMPRESA BRASILEIRA DE PESQUISA AGROPECUÁRIA - EMBRAPA. Manual de métodos de análises de solo. 2.ed. Rio de Janeiro, Ministério da Agricultura e do Abastecimento, 1997. 212p.

FRANCO, A.A. \& BALIEIRO, F.C. Fixação biológica de nitrogênio: Alternativa aos fertilizantes nitrogenados. In: SIQUEIRA, J.O.; MOREIRA, F.M.S.; LOPES, A.S.; GUILHERME, L.R.G.; FAQUIN, V.; FURTINI NETO, A.E. \& CARVALHO, J.G., eds. Inter-relação fertilidade, biologia do solo e nutrição de plantas. Viçosa, MG, Sociedade Brasileira de Ciência do Solo, 1999. p.577596.

GARG, N. \& SINGLA, P. Arsenic toxicity in crop plants: Physiological effects and tolerance mechanisms. Environ. Chem. Lett., 9:303-321, 2011.

GONZAGA, M.I.S.; SANTOS, J.A.G. \& MA, L.Q. Arsenic phytoextraction and hyperaccumulation by fern species. Sci. Agric., 63:90-101, 2006.

KARNOVSKY, M.J. A formaldehyde-glutaraldehyde fixative of high osmolality for use in electron microscopy. J. Cell Biol., 27:137-138, 1965.

GRAEL, C.F.F.; KANASHIRO, A.; KABEYA, L.M.; JORDÃO, C.O.; TAKEARA, R.; GOBBO-NETO, L.; POLIZELLO, A.C.M.; LUCISANO-VALIM, Y.M.; LOPES, N.P. \& LOPES, J.L.C. In vitro study of antioxidant and scavenger properties of phenolic compounds from Lychnophora species. Quím. Nova, 33:867-870, 2010.

KYLE, J.H.; BREUER, P.L.; BUNNEY, K.G.; PLEYSIER, R. \& MAY, P.M. Review of trace toxic elements $(\mathrm{Pb}, \mathrm{Cd}$, $\mathrm{Hg}, \mathrm{As}, \mathrm{Sb}, \mathrm{Bi}, \mathrm{Se}, \mathrm{Te}$ ) and their deportment in gold processing. Part 1: Mineralogy, aqueous chemistry and toxicity. Hydrometallurgy, 107:91-100, 2011.

LITTER, M.; CARRERA, A.P.; MORGADA, M.E.; RAMOS, O.; QUINTANILLA, J. \& FERNÁNDEZ-CIRELLI, A. Formas presentes de arsénico en agua y suelo. In: BUNDSCHUH, J.; CARRERA, A.P. \& LITTER, M., eds. Distribución del arsénico en las regiones ibérica e iberoamericana. Buenos Aires, CYTED, 2008. p.5-32. 
LITTER, M.I.; ALARCÓN-HERRERA, M.T.; ARENAS, M.J.; ARMIENTA, M.A.; AVILÉS, M.; CÁCERES, R.E.; CIPRIANI, H.N.; CORNEJO, L.; DIAS, L.E.; CIRELLI, A.F.; FARFÁN, E.M.; GARRIDO, S.; LORENZO, L.; MORGADA, M.E.; OLMOS-MÁRQUEZ, M.A. \& PÉREZCARRERA, A. Small-scale and household methods to remove arsenic from water for drinking purposes in Latin America. Sci. Total Environ., 429:107-122, 2012.

MADEIRA, A.C.; ESTEVES, C.; ABREU, M.M.; VARENNES, A. \& MAGALHÃES, M.C.F. Comparação de correctivos aplicados a um solo de uma área mineira contaminado com arsénio e seu efeito no crescimento de plantas. R. Ci. Agrár. (Lisb. Impr.), 33:31-40, 2010.

MANDAL, B.K. \& SUZUKI, K.T. Arsenic round the world: A review. Talanta, 58:201-235, 2002.

MARQUES, A.P.G.C.; RANGEL, A.O.S.S. \& CASTRO, P.M.L. Remediation of heavy metal contaminated soils: phytoremediation as a potentially promising clean-up technology. Crit. Rev. Environ. Sci. Technol., 39:622-654, 2009.

MARTO, G.B.T. Acacia mangium (Acácia). 2007. Available: $<$ http://www.ipef.br/identificacao/acacia.mangium.asp>. Accessed date: Aug. 6, 2012.

MELO, R.F.; DIAS, L.E.; MELLO, J.W.V. \& OLIVEIRA, J.A. Behavior of Eucalyptus grandis and E. cloeziana seedlings grown in arsenic-contaminated soil. R. Bras. Ci. Solo, 34:985-992, 2010.

NASCIMENTO, C.W.A.; ACCIOLY, A.M.A. \& BIONDI, C.M. Fitoextração de metais pesados em solos contaminados: Avanços e perspectivas. In: RIBEIRO, M.R.; NASCIMENTO, C.W.A.; RIBEIRO FILHO, M.R. \& CANTALICE, J.R.B., eds. Tópicos em ciência do solo. Viçosa, MG, Sociedade Brasileira de Ciência do Solo, 2009. v.6. p.461-497.

NASCIMENTO. K.J.T.; OLIVEIRA, J.A.; CAMBRAIA, J. \& OLIVA, M.A. Alterações do sistema de defesa antioxidativo em plântulas de Stizolobium aterrimum e Canavalia ensiformis expostas ao arsênio. J. Braz. Soc. Ecotoxicol., 6:37-42, 2011.

PEREIRA, F.J.; CASTRO, E.M.; OLIVEIRA, C.; PIRES, M.F. \& PASQUAL, M. Mecanismos anatômicos e fisiológicos de plantas de aguapé para a tolerância à contaminação por arsênio. Planta Daninha, 29:259-267, 2011.

PULFORD, I.D. \& DICKINSON, N.M. Phytoremediation technologies using trees. In: PRASAD, M.N.V.; SAJWAN, K.S. \& NAIDU, R., eds. Trace elements in the environment: Biogeochemistry, biotechnology and bioremediation. Boca Raton, CRC, 2005. p.375-395.
RIBASKI, J.; LIMA, P.C.F.; OLIVEIRA, V.R. \& DRUMOND, M.A. Sabiá (Mimosa caesalpiniaefolia): Àrvore de múltiplo uso no Brasil. Colombo, Embrapa, 2003. (Comunicado Técnico, 104)

SANTOS, J.A.; GONZAGA, M.I. \& MA, L.Q. Optimum P levels for arsenic removal from contaminated groundwater by Pteris vittata L. of different ages. J. Hazard. Mater., 180:662-667, 2010.

SCHNEIDER, J.; LABORY, C.R.G.; RANGEL, W.M.; ALVES, E. \& GUILHERME, L.R.G. Anatomy and ultrastructure alterations of Leucaena leucocephala (Lam.) inoculated with mycorrhizal fungi in response to arseniccontaminated soil. J. Hazard. Mater., dx.doi.org/10.1016/ j.jhazmat.2012.05.091, 2012.

SHAIBUR, M.R.; KITAJIMA, N.; SUGAWARA, R.; KONDO, T.; HUQ, S.H.I. \& KAWAI, S. Physiological and mineralogical properties of arsenic-induced chlorosis in barley seedlings grown hydroponically. J. Plant Nutr., 31:333-353, 2008.

SILVA, K.L.F. Avaliações de biomarcadores anatômicos e fisiológicos em plantas expostas ao arsênio. Viçosa, MG, Universidade Federal de Viçosa, 2008. 109p. (Tese de Doutorado)

SRIDHAR, B.B.M.; HAN, F.X.; DIEHL, S.V.; MONTS, D.L. \& SU, Y. Effect of phytoaccumulation of arsenic and chromium on structural and ultrastructural changes of brake fern (Pteris vittata). Braz. J. Plant Physiol., 23:285-293, 2011.

TEDESCO, M.J.; GIANELLO, C.; BISSANI, C.A.; BOHNEN, H. \& VOLKWEISS, S.J. Análise de solo, plantas e outros materiais. Porto Alegre, Universidade Federal do Rio Grande do Sul, 1995. 174p.

VAUGHAN, D.J. Arsenic. Elements, 2:71-75, 2006.

WANG, F.; LI, Z.; XIA, H.; ZOU, B.; LI, N.; LIU, J. \& ZHU, W. Effects of nitrogen-fixing and non-nitrogen-fixing tree species on soil properties and nitrogen transformation during forest restoration in southern China. Soil Sci. Plant Nutr., 56:297-306, 2010.

WANG, S.; ZHANG, D. \& PAN, X. Effects of arsenic on growth and photosystem II (PSII) activity of Microcystis aeruginosa. Ecotoxicol. Environ. Saf., dx.doi.org/10.1016/ j.ecoenv.2012.06.028, 2012.

ZHAO, F.J.; MA, J.F.; MEHARG, A.A. \& McGRATH, S.P. Arsenic uptake and metabolism in plants. New Phytol., 181:777-794, 2009.

ZHAO, F.J.; McGRATH, S.P. \& MEHARG, A.A. Arsenic as a food chain contaminant: Mechanisms of plant uptake and metabolism and mitigation strategies. Ann. Rev. Plant Biol., 61:535-559, 2010. 